\title{
Kenestä erikoiskasviviljelijäksi? Erikoiskasviviljelyn omaksujatyypit ja omaksumisen taustalla vaikuttavat tekijät.
}

\author{
Heli Vuorio ${ }^{1)}$, Katriina Soini ${ }^{l)}$ ja Arsi Ikonen ${ }^{l)}$ \\ ${ }^{1)}$ MTT (Maa- ja elintarviketalouden tutkimuskeskus) Ympäristöntutkimus, 31600 Jokioinen, \\ heli.vuorio@mtt.fi; katriina.soini@mtt.fi ; $\underline{\text { arsi.ikonen@mtt.fi }}$
}

\section{Tiivistelmä}

Erikoiskasviviljely saattaa tulevaisuudessa olla vakavasti otettava vaihtoehto tiloilla, joilla halutaan jatkaa kasvinviljelyä. Kasvinviljely on tällä hetkellä Suomessa hyvin yksipuolista: lähes puolet kaikista tiloista viljelee vain yhtä viljakasvia ja vain noin $13 \%$ tiloista vähintään kolmea eri kasvia. Erikoisempia kasveja, kuten kuminaa, pellavaa, ruokohelpiä ja tattaria viljellään jossain määrin, mutta todellista läpimurtoa näiden erikoisempien kasvien viljelyssä ei vielä ole tapahtunut. Erikoiskasviviljely kuitenkin tukee EU:n viimeaikaisen maatalous-, maaseutu- ja ympäristöpolitiikan tavoitteita.

MTT:ssa toteutetussa Monikasvi-hankkeen osatutkimuksessa selvitettiin erikoiskasviviljelyä viljelijöiden näkökulmasta. Tutkimuksen tavoitteena oli 1) karakterisoida erikoiskasviviljelyinnovaation omaksujat ja torjujat, 2) selvittää innovaation omaksumisen taustalla vaikuttavat tekijät, 3) tutkia, millaiseksi vaihtoehdoksi viljelijät mieltävät erikoiskasviviljelyn tulevaisuudessa ja 4) ja näiden tulosten perusteella selvittää, miten erikoiskasviviljelyä voitaisiin edistää. Tiedon kartoittamiseksi tehtiin internetin välityksellä kysely, johon vastasi 1051 viljelijää.

Kyselyn perusteella erikoiskasviviljelyinnovaation omaksujat ovat yleensä hieman keskimääräistä korkeammin koulutettuja ja lähes pääsääntöisesti kasvinviljelijöitä. Erikoiskasviviljelijöiden joukossa on myös keskiarvoa enemmän luomuviljelijöitä. Erikoiskasviviljelijöissä on runsaasti niitä, joiden kotitalouden tulojen pääosa tulee maa- ja metsätalouden ulkopuolelta. Innovaation omaksujat ja siitä erittäin kiinnostuneet suunnittelevat keskimääräistä useammin tilan tuotannon laajentamista tai merkittävää muutosta lähiaikoina.

Erikoiskasviviljelijöillä on muita viljelijöitä enemmän kokemusta myös muiden kuin ns. tavanomaisten viljakasvien viljelystä. Erikoiskasviviljelijöitä kiinnostaa myös non-food -kasvien viljely, kun taas innovaation torjujat haluavat pitäytyä tutuissa viljelykasveissa. Erikoiskasviviljely näyttäisi siten sopivan viljelijälle, joka on innostunut kokeilemaan uusia viljelykasveja, etsimään vaihtelua tilan toimintaan ja tavoittelemaan tilan tunnettavuutta. Kaikkiaan tutuimpia erikoiskasveja olivat kumina, tattari, öljypellava, kuitupellava ja härkäpapu. Erikoiskasveja viljelemättömät pitivät houkuttelevampina vaihtoehtoina kuminaa, ruokohelpiä, tarttaria, spelttiä sekä öljy- ja kuitupellavaa.

Erikoiskasviviljelyinnovaation omaksumisen taustalla on selkeästi taloudellisia hyötynäkökohtia. Viljelijöiden mielestä erikoiskasviviljelyn suurin ympäristöhyöty on maan rakenteen paraneminen erikoiskasveihin perustuvan viljelykierron kautta. Erikoiskasviviljelystä vakavasti kiinnostuneet suhtautuvat muita luottavaisemmin erikoiskasvien markkinoiden kehittymiseen ja pitävät erikoiskasviviljelyn imagoa keskimääräistä parempana. Erikoiskasviviljelyn ei katsottu olevan viljelyteknisesti oleellisesti tavanomaista viljelyä haasteellisempaa tai työläämpää.

Vastaajien mielestä erikoiskasveista ei nykyisellään ole riittävästi tietoa tarjolla, mutta tiedonsaanti ei ole ollut esteenä viljelyyn ryhtymiselle. Viljelystä kiinnostuneet ovat etsineet tarvittavan ammattilehdistä, tutulta viljelijältä, koulutustilaisuuksista tai internetistä. Toisten viljelijöiden kokemukset osoittautuivat yllättävän tärkeiksi viljelyn aloittamispäätöstä tehtäessä ja myöhemminkin viljelyn aikana.

Asiasanat: erikoiskasvit, kyselytutkimus, maanviljelijät, innovaatiot, omaksujatyypit 


\section{Johdanto}

Viimeisen kymmenen vuoden aikana suomalaisen maatalouden rakenne on muuttunut rajusti lähinnä kansainvälisen kaupan vapautumisen ja EU:n yhteisen maatalouspolitiikan seurauksena. Tilojen määrä on vähentynyt ja keskimääräinen tilakoko suurentunut, ja tämä kehityslinjan on ennustettu jatkuvan myös tulevaisuudessa (Niemi \& Pietola 2005). Kasvinviljelyn jatkaminen edellyttää joko viljelypintaalan kasvattamista tai erikoistumista katetuotoltaan keskimääräistä parempiin kasveihin.

Viime vuosina EU:n maatalous-, maaseutu- ja ympäristöpolitiikassa on korostettu tuotannollisten arvojen rinnalla myös maatalouden muita arvoja, kuten huoltovarmuutta, maaseudun elinvoimaisuutta, maatalousluonnon monimuotoisuutta ja maisemallisia arvoja (Council of European Union 2003). Kasvinviljelyn monipuolistaminen, joka parhaimmillaan voi parantaa viljelymaan tilaa, edistää luonnon monimuotoisuutta, lisätä maisemallista monimuotoisuutta, tuottaa vaihtoehtoisia raaka-aineita teollisuuteen, pienyritystoimintaan ja energiahuoltoon, tukee useita näistä politiikkatavoitteista. Vaikka monimuotoinen kasvinviljely on linjassa EU:n politiikkatavoitteiden kanssa, on kasvinviljely Suomessa edelleen hyvin yksipuolista. Lähes puolet kaikista tiloista viljelee vain yhtä viljakasvia ja vain noin $13 \%$ tiloista vähintään kolmea eri kasvia (Maatilarekisteri 2002).

Käsillä oleva työ on Monikasvi ${ }^{1}$-tutkimushankkeen osatutkimus, jossa selvitetään erikoiskasviviljelyä viljelijöiden näkökulmasta. Erikoiskasveilla tarkoitetaan tässä yhteydessä erikoisempia yksi- ja kaksivuotisia viljelykasveja kuten kuminaa, ruokohelpiä, tattaria, kitupellavaa ja värimorsinkoa. Näiden kasvien viljelyä lähestytään innovaationa, kasvinviljelyuutuutena. Lähtöoletuksena on, että erikoiskasviviljelyyn ryhtymiseen vaikuttavat taloudellisten tekijöiden lisäksi monet sosiaaliset ja kulttuuriset tekijät, kuten maatalouden harjoittamista koskevat arvot ja päämäärät, sosiaaliset normit sekä erikoiskasveja koskeva tietous ja viljelijöiden omakohtaiset kokemukset. Tutkimuksen tavoitteena on 1) karakterisoida erikoiskasviviljelyinnovaation omaksujat ja torjujat, 2) selvittää innovaation omaksumisen taustalla vaikuttavat tekijät, 3) tutkia, millaiseksi vaihtoehdoksi viljelijät mieltävät erikoiskasviviljelyn tulevaisuudessa ja 4) ja näiden tulosten perusteella selvittää, miten erikoiskasviviljelyä voisi edistää.

Erikoiskasviviljely täyttää innovaatiolle sopivat kriteerit monestakin näkökulmasta. Osa kasveista, kuten värimorsinko ja kinua ovat suhteellisen uusia viljelykasveja Suomessa tai jollakin tietyllä alueella (Keskitalo 2000). Osa puolestaan on perinteisempiä suomalaisia kasveja, joiden viljely on aikoinaan väistynyt tuottavampien ja kysytympien tuotantokasvien tieltä. Nämä kasvit voivat olla yksittäisille viljelijöille uusia ja siksi niiden käyttöönotto voidaan ymmärtää innovaation omaksumiseksi. Lisäksi viljelytekniikat ovat kehittyneet, joten myös perinteisten viljelylajien ja uusien teknisten ratkaisujen yhdistämisessä on innovaation piirteitä. Monia kasveja ei myöskään ole aiemmin hyödynnetty kaupallisesti tai laajamittaisessa tuotannossa.

Innovaatioiden omaksumisesta ja leviämisestä on useita teorioita (Hägerstrand 1953, Rogers 2003, Luostarinen 2004). Tässä tutkimuksessa innovaatioiden omaksumista on tarkasteltu pääasiassa Rogersin $^{2}$ (2003) esittämän luokituksen pohjalta, koska tutkimuksen tavoitteena on selvittää nimenomaan erikoiskasvi-innovaation omaksujiin eli viljelijöihin liittyviä tekijöitä, joita ei aiemmissa tutkimuksissa ole selvitetty. Innovaation omaksumisteorioita on hyödynnetty myös mm. suomalaisten luomuviljelijöiden ominaispiirteitä selvitettäessä (Lehtinen \& Salo 2000, Roslakka 2005).

Innovaation omaksumiseen vaikuttaa useita tekijöitä, jotka voivat liittyä itse innovaatioon tai innovaation omaksujan piirteisiin sekä ympäröiviin olosuhteisiin. Tutkimuksessa erikoiskasviviljelyinnovaation omaksumisalttiutta tarkastellaan viiden erilaisen tekijän avulla (vrt. Rogers 2003, Guerin 2001). Nämä tekijät ovat a) innovaation tuottama taloudellinen tai muu hyöty, b) viljelijän päämäärät, asenteet ja aikaisemmat kokemukset, c) itse innovaation mutkikkuus ja sen

\footnotetext{
${ }^{1}$ Vuonna 2003 käynnistyneessä Monikasvi -hankkeessa ryhdyttiin tutkimaan tarkemmin yhdeksää erikoiskasvia, viljelyn vaikutuksia maatalousympäristön monimuotoisuuteen, viljelyn taloudellisia edellytyksiä sekä hyväksyttävyyttä viljelijöiden ja kuluttajien kannalta. Monikasvi -hanke kuuluu LUMOpelto-projektiin, joka on osa maa- ja metsätalousministeriön rahoittamaa Monimuotoisuuden tutkimusohjelmaa (MOSSE).

${ }^{2}$ Rogers, E.M. on yksi tunnetuimmista innovaatioteoreetikoista. Ensimmäisen teoriansa hän esitti jo vuonna 1962 kirjassaan Diffusion of Innovations. Sittemmin tuosta kirjasta on ilmestynyt uusia painoksia vuosina 1971,1983, 1995 ja viimeksi vuonna 2003, jossa mallia on edelleen kehitetty ja laajennettu.
} 
tuttuus, d) uuden innovaation havainnointiin ja testaamiseen vaikuttavat tekijät sekä e) innovaatioon liittyvä kommunikointi ja tiedonvälitys.

\section{Aineisto ja menetelmät}

Erikoiskasviviljelyä koskevaa yhteiskunnallista tutkimusta ei juuri ole Suomessa tehty. Siksi tutkimuskysymysten täsmentäminen vaati esitutkimuksen, jossa kartoitettiin millaisista teemoista käsin erikoiskasviviljelyä on tarkoituksenmukaista lähestyä varsinaisessa viljelijöille suunnatussa kyselyssä. Teemojen kartoittaminen toteutettiin nk. avaininformanttien taustahaastattelulla (yht. $6 \mathrm{kpl}$ ) kesällä 2003.

Tutkimuksen varsinainen aineisto koostui kevättalvella 2004 internetissä toteutetun kyselyn vastauksista. Kyselylomakkeen levittämisessä hyödynnettiin maaseutuelinkeinorekisteriin koottuja viljelijöiden sähköpostiosoitteita, joita saatiin käyttöön yhteensä noin 7000 . Kysely lähetettiin sähköpostitse niille rekisterin viljelijöille, jotka olivat antaneet luvan käyttää tietojaan tutkimuksia varten. Ennen kyselyn lähettämistä julkaistiin Maaseudun Tulevaisuudessa 28.1.2004 artikkeli, jolla pyrittiin innostamaan viljelijöitä vastaamaan. Lisäksi MTK:n nettisivuilla sekä Reppuintranetpalvelussa oli suoralinkki kyselyyn pienen mainoksen kera. Koska osa viljelijöistä pahoitteli kyselyn toteuttamista alunperin vain suomen kielellä, kysely toteutettiin helmikuun 2004 lopulla myös ruotsin kielellä. Tyhjien ja virheellisten vastausten karsimisen sekä puuttuvien tietojen korjauksen jälkeen vastausten lopullinen lukumäärä oli 1020. Tutkimuksen toteutustavasta johtuen vastaajiksi ovat valikoituneet herkemmin nuoremmat sekä tietokoneen kanssa työskentelevät viljelijät.

Aineiston tilastomatemaattisissa analyyseissä käytettiin pääasiassa ristiintaulukointia ja $\mathrm{Khii}^{2}$ testiä (Zar 1999). Mediaanitestiä sovellettiin $\mathrm{Khii}^{2}$-testin sijaan silloin, kun testattiin nimenomaan vastausjakaumien keskikohtien sijainnin eroavuutta. Eksakteihin testeihin turvauduttiin niissä tapauksissa, joissa asymptoottisen testin käyttö ei ollut mahdollista solukohtaisten odotettujen frekvenssien pienuuden vuoksi. Eräissä tapauksissa edes tehokkaan PC:n laskentateho ei riittänyt eksaktin testin laskemiseen, jolloin laskettiin eksaktin P-arvon Monte Carlo -estimaatti 100000 näytteellä. P-arvojen liukuvaa Bonferroni-korjausta käytettiin useiden rinnakkaisten testausten yhteydessä (Rice 1989). Tilastolliset testit tehtiin SAS 9.1- ja SPSS 12.0.1 -ohjelmistoilla.

\section{Tulokset ja tulosten tarkastelu}

\section{Vastaajaryhmät ja erikoiskasviviljely}

Tutkimusaineistosta oli löydettävissä viisi erilaista viljelijäryhmää (Kuvio 1). Ensimmäiseen ryhmään (I) kuuluivat vastaajat, jotka viljelivät jotakin mainituista erikoiskasveista. Toisen ryhmän (II) muodostivat vastaajat, joilla oli ollut aiemmin viljelykierrossa erikoiskasveja, mutta olivat luopuneet viljelystä syystä tai toisesta. Seuraavilla kolmella ryhmällä ei ollut viljelykokemusta erikoiskasveista ja heidän mielenkiintonsa niiden viljelyn aloittamisesta vaihteli: ryhmän kolme (III) vastaajat olivat viljelyn aloittamisesta erittäin kiinnostuneita, ryhmän neljä (IV) mahdollisesti kiinnostuneita ja ryhmän viisi (V) vastaajat eivät nähneet erikoiskasveja itselleen mahdollisena vaihtoehtona.
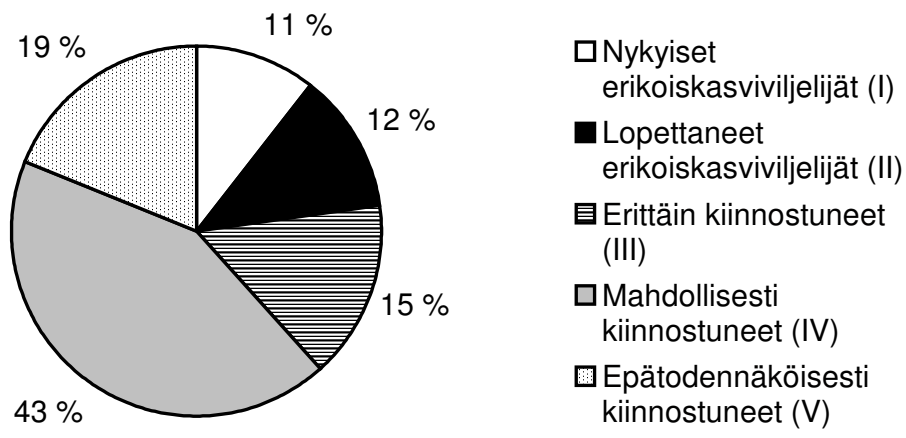

Kuvio 1. Vastaajaryhmät ja niiden suhteelliset osuudet koko aineistosta. 
Erikoiskasvilajien viljelyn yleisyys vaihteli erittäin merkitsevästi. Erikoiskasvilajeista ylivoimaisesti useimmin viljelty kasvi oli ollut kumina, jonka viljelystä oli kokemusta 45,3 \%:lla kaikista erikoiskasviviljelijöistä (ryhmät I ja II). Erikoiskasviviljelijöistä 24,1 - 26,7 \%:lla oli kokemusta tattarin tai öljypellavan viljelystä, 16,4 \%:lla kuitupellavan ja 14,2 \%:lla härkäpavun viljelystä. Muiden erikoiskasvilajien viljely oli ollut keskimäärin vähäistä. Erikoiskasveja viljelemättömistä (ryhmät III-V) kiinnostavimpina lajeina pidettiin kuminaa (27,5\% vastaajista), ruokohelpiä $(16,4 \%)$, tattaria $(13,8 \%)$, spelttiä $(12,0 \%)$, öljypellavaa $(11,3 \%)$ sekä kuitupellavaa $(9,5 \%)$. Muut erikoiskasvit herättivät vain vähäistä mielenkiintoa (Kuvio 2.)

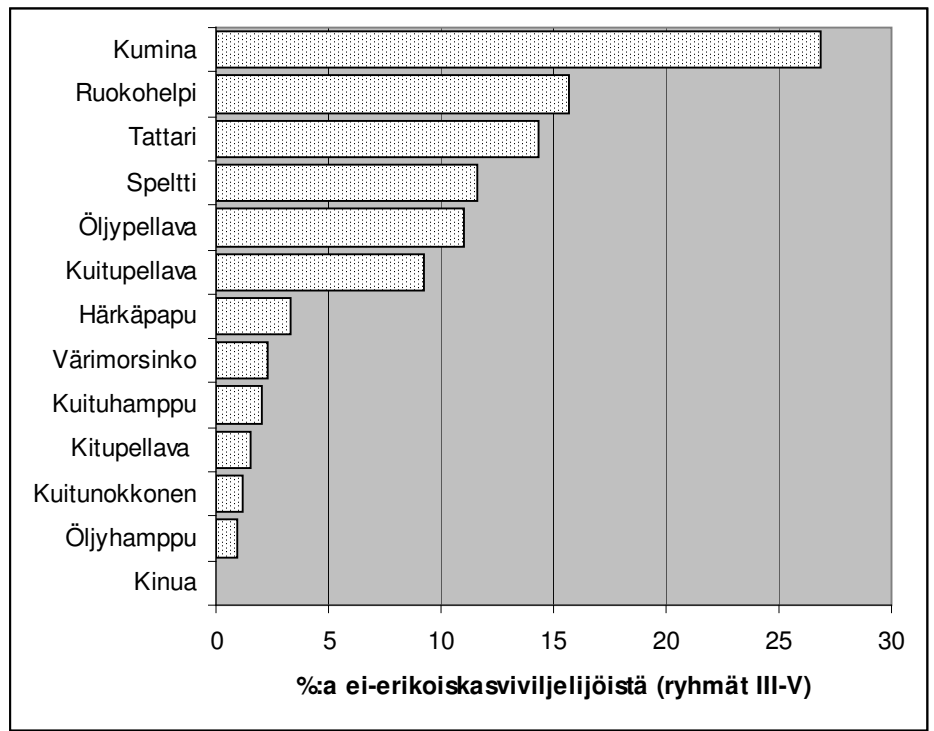

Kuvio 2. Kiinnostavimmat erikoiskasvit erikoiskasveja kokeilemattomien viljelijöiden joukossa.

Tutkimus osoitti, että jatkavat erikoiskasviviljelijät (ryhmä I) eli innovaation omaksuneita luonnehtivat useat ominaispiirteet. Erikoiskasviviljelijät olivat vastaajien keskimääräistä tasoa korkeammin koulutettuja sekä muita ryhmiä useammin pääsääntöisiä kasvinviljelijöitä. Erikoiskasviviljelijöissä oli runsaammin niitä, joiden kotitalouden tulojen pääosa tuli maa- ja metsätalouden ulkopuolelta. Innovaation omaksujat ilmoittivat keskiarvoa useammin suunnittelevansa tilan tuotannon laajentamista tai merkittävää muutosta lähiaikoina. Jatkavien erikoiskasviviljelijöiden joukossa oli myös enemmän luomuviljelijöitä suhteessa koko viljelijäväestöön.

Jatkavilla erikoiskasviviljelijöillä oli tavallisesti aiempaakin kokemusta myös muiden kuin ns. tavanomaisten viljakasvien viljelystä. Tätä selittää osittain se, että jatkavat erikoiskasviviljelijät olivat lähes yksinomaan kasvinviljelijöitä. Jatkavia erikoiskasviviljelijöitä kiinnosti myös non-food -kasvien viljely, kun taas innovaation torjujat ilmoittivat haluavansa pitäytyä tutuissa viljelykasveissa. Jatkavat erikoiskasviviljelijät näyttivät oleva aktiivisia yhteistyössä muiden viljelijöiden kanssa. Aktiivisuus luo sosiaalisten yhteyksien verkoston, jonka kautta viljelijä saa tietoa innovaatiosta useista eri lähteistä. Jatkavat erikoiskasviviljelijät olivat myös kaikkein aktiivisimpia kasvien viljelyä koskevassa tiedonhankinnassa. Kaiken kaikkiaan erikoiskasviviljelijät näyttävät olevan innostuneita kokeilemaan uusia viljelykasveja, etsimään vaihtelua tilan toimintaan ja tavoittelemaan tilan tunnettavuutta.

Erikoiskasviviljelyn lopettaneilla (ryhmä II) ja jatkavilla erikoiskasviviljelijöillä (ryhmä I) oli paljon yhtäläisyyttä mm. tilaan ja toimintatapaan (yhteistyön tekeminen, tiedonhankinta) liittyvien tekijöiden osalta. Näiden kahden ryhmän suurimmat erot löytyvät erikoiskasviviljelyn aloittamispäätöksen taustalla vaikuttaneista tekijöistä kuten viljelyn markkinanäkymistä. Ryhmällä II lopettamispäätöksen taustalla oli usein juuri pettymys viljelyn kannattavuuteen. Erikoiskasviviljelyn lopettaneet olivat tehneet vähemmän investointeja erikoiskasviviljelyyn kuin sitä edelleen jatkavat. Lopettaneet erikoiskasviviljelijät puolestaan arvostivat jatkajia enemmän viljelyn riskittömyyttä. Tulokset viittaavat siihen, että erikoiskasviviljelyn lopettaneet viljelijät eivät välttämättä ole olleet alunperinkään yhtä sitoutuneita erikoiskasviviljelyyn kuin sitä jatkavat. Lopettaneiden erikoiskasviviljelijöiden riskinottokyky ja -halu olivat alhaisempia kuin jatkavilla viljelijöillä. 
Mielenkiintoisin ja erikoiskasviviljelyn lisäämisen kannalta ehdottomasti tärkein ryhmä on viljelystä erittäin kiinnostuneet (ryhmä III), joilla oli yhtäläisyyksiä nykyisten erikoiskasviviljelijöiden kanssa viljelyyn liittyvien tavoitteiden, kuten maaperän hyvinvoinnin parantamisen ja tiedonhankinnan osalta. Tämä viittaa siihen, että ainakin osa ryhmästä III voisi henkilökohtaisen neuvonnan ja rohkaisun myötä ryhtyä erikoiskasviviljelijöiksi. Ryhmän III tiloilla pohditaan myös keskimääräistä useammin tuotannon jatkamisen vaihtoehtoja. Erikoiskasveista mahdollisesti kiinnostuneet (ryhmä IV) jakoi monia näkemyksiä erikoiskasveista erittäin kiinnostuneiden (ryhmä III) viljelijöiden kanssa. Ryhmän IV viljelijät olivat kuitenkin hieman epäilevämpiä erikoiskasvien viljelytekniikan suhteen. Ympäristötekijöillä ei myöskään ollut ryhmälle IV yhtä suurta merkitystä kuin ryhmälle III, vaan ryhmän IV viljelyn motiivit liittyvät ensisijaisesti taloudellisiin tekijöihin. Mikäli erikoiskasviviljely osoittautuisi riittävän kannattavaksi pitkällä tähtäimellä, se saattaisi tulla kysymykseen myös ryhmän IV viljelijöille.

Erikoiskasveihin kriittisimmin suhtautuvista viljelijöistä (ryhmä V) merkittävä osa oli eläintilallisia. Erikoiskasviviljely ei ole heidän tiloillaan kovin todennäköinen vaihtoehto, koska kasvintuotanto halutaan säilyttää yksinkertaisena, eikä kiinnostusta esimerkiksi non-food -kasveihin ollut havaittavissa. Tämän ryhmän vastaukset olivat myös pessimistisimpiä koko maatalouden tulevaisuuden suhteen. Ryhmän V viljelijät kokivat tilojen tuotannon jatkumisen ja tulevaisuuden kaikkein epävarmimpana.

\section{Erikoiskasviviljelyn omaksumiseen vaikuttavat tekijät}

A) Innovaation tuottama hyöty. Erikoiskasviviljelyinnovaation omaksumisen taustalla on selkeästi taloudellisia hyötyjä. Innovaation omaksujat ovat yleisesti sitä mieltä, että heidän valitsemallaan erikoiskasvilla on hyvät markkinanäkymät. Tosin erikoiskasvinviljely on usein varsin pienimuotoista, usein viljelyala jää alle 10 hehtaarin. Vain $14 \%$ :lla kyselyyn vastanneista tiloilla erikoiskasvien osuus nettomaataloustulosta on yli puolet. Viljelyn taloudellisista motiiveista kertoo se, että erikoiskasviviljelystä luopuneet (ryhmä II) olivat pettyneet erikoiskasviviljelyn alhaiseen katetuottoon. He näkivät myös ongelmia erikoiskasvien jatkojalostus- ja markkinointiketjussa.

Tutkimuksen perusteella voidaan todeta, että taloudelliset tekijät voivat lyhytaikaisesti kannustaa erikoiskasvien viljelyyn, mutta pitkäjänteisempi viljely edellyttää myös muunlaisten arvoja ja tekijöitä. Yksi niistä voi liittyä $\mathrm{mm}$. tilan imagon paranemiseen. Erikoiskasviviljelijöiden motivaatiotekijöissä korostuivat muita ryhmiä vahvemmin viljelijän oma kokeilunhalu ja erikoistumishalu. Viljelijöiden mielestä erikoiskasviviljelyn suurin ympäristöhyöty on maan rakenteen paraneminen erikoiskasveihin perustuvan viljelykierron kautta.

B) Päämäärät, asenteet ja aikaisemmat kokemukset. Kuten aiemmin todettiin, erikoiskasviviljelijöitä luonnehtivat kokeilunhalu ja riskinottokyky, mikä näkyy siinä, että heillä on jo aiempaa kokemusta monipuolisesta kasvinviljelystä ja he ovat halukkaita investoimaan uusien kasvien vaatimiin koneisiin ja laitteisiin. Uusia kasveja halutaan viljellä, vaikka siihen liittyisikin riskejä. Ympäristöasenteita ei tässä tutkimuksessa laajamittaisesti testattu, mutta erikoiskasviviljely miellettiin ympäristöystävällisevänä tuotantotapana. Erikoiskasviviljelyn ja luomuviljelyn taustalla vaikuttavat arvot ja päämäärät ovatkin hyvin samantapaisia, samoin kuin itse innovaatiokin on. Tätä havaintoa tukee myös se, että nykyisistä erikoiskasviviljelijöistä on keskimääräistä suurempi osa luomuviljelijöitä.

C) Innovaation mutkikkuus. Erikoiskasviviljelyä ei pidetä yleensä kovin mutkikkaana innovaationa. Viljelijät arvioivat viljelykasvia valitessaan kasvin ominaisuuksia ja viljelyteknisiä vaatimuksia sekä vaikutuksia maaperän hyvinvoinnin kannalta. Uusien lajikkeiden kokeilu tai testaus edellyttää asiaan paneutumista. Erikoiskasveja kokeilemattomat viljelemättömät kokivat vaikeana mm. siementen saatavuuden. Erikoiskasveja viljelleillä on ollut sopivaa kalustoa, eikä lisäinvestointeja ole juuri tarvinnut tehdä, ja edelleen kaluston sopivuus oli juuri yksi tärkeä ehto viljelyn aloittamiselle. Potentiaaliset erikoiskasviviljelijät olivat kuitenkin valmiita tekemään investointeja, jopa enemmän kuin mitä viljely käytännössä edellyttäisi.

Yleensä ottaen erikoiskasvien viljelyn ei katsottu olevan viljelyteknisesti oleellisesti haasteellisempaa tai työläämpää, vaikka yllätyksiäkin on tullut: monilla erikoiskasviviljelijöillä on ollut ongelmia tuholaisten ja kasvitautien torjunnassa, vaihtelut sadon määrässä ovat yllättäneet ja kasvien talvehtiminen on ollut heikkoa. On mahdollista, että erikoiskasviviljelyyn liittyvät odotukset 
ovat tavanomaisten kasvien viljelyyn verrattuna suurempia. Siksi vastoinkäymiset ja pettymykset saattavat johtaa helposti viljelystä luopumiseen.

D) Havainnointi- ja testausmahdollisuus. Innovaation omaksumista tukee, jos viljelijällä on mahdollisuus testata sitä käytännössä tai havainnoida esimerkiksi naapuritilan kokemuksia viljelystä. Erikoiskasviviljelyn testaamismahdollisuus riippuu sekä tilan olosuhteista että olemassa olevasta kalustosta. Vastaajat totesivat tilansa vastaavan melko hyvin erikoiskasviviljelyn asettamiin vaateisiin, joka osaltaan kannustaa viljelyn kokeilemista. Tutkimuksen mukaan erikoiskasviviljelijät olivat olleet muita ryhmiä enemmän tekemissä lähiympäristön viljelijöiden kanssa yhteistyön välityksellä. Tämän myötä tulevat kontaktit lisännevät todennäköisyyttä, että viljelijä tutustuu uusiin viljelyvaihtoehtoihin toisten viljelijöiden kokemuksien kautta.

E) Innovaatioon liittyvä kommunikointi ja tiedonvälitys. Kumina oli selvästi tunnetuin tutkimukseen kuuluneista erikoiskasveista. Kuminaa viljellään myös eniten, ja viljelijät olivat siitä myös kaikkein kiinnostuneimpia kyselyn toteuttamishetkellä. Myös öljy- ja kuitupellava, tattari, speltti ja ruokohelpi olivat kohtuullisen hyvin tunnettuja, ja ne nähtiin myös potentiaalisina viljelykasveina. Sen sijaan värimorsinko, öljy- ja kuituhamppu, kitupellava ja kinua olivat viljelijöille vieraita. Tutummat kasvit koettiin pääsääntöisesti myös mielenkiintoisimmiksi viljelyvaihtoehdoiksi. Tutkimus osoitti, että erikoiskasvien viljelyominaisuuksia koskevat kokemukset poikkesivat ennakkokäsityksistä, mikä korostaa erikoiskasviviljelyä koskevan tutkimuksen, tiedottamisen ja kokemusten vaihdon tärkeyttä.

Vastaajien mielestä erikoiskasveista ei ole riittävästi tietoa tarjolla, mutta tiedonsaanti ei ole ollut esteenä viljelyyn ryhtymiselle: ne, jotka ovat olleet kiinnostuneita viljelystä, ovat 'kaivaneet' tarvittavan tiedon esille pääsääntöisesti omatoimisesti ammattilehdistä tai internetistä, mutta tärkeä merkitys on ollut myös tutun viljelijän kokemuksilla sekä koulutustilaisuuksilla. Yllättävän tärkeäksi tietokanavaksi ja viljelyn aloittamiseen johtavana tekijäksi nousi toisten viljelijöiden kokemukset. 'Naapuruusefekti' (Hägerstrand 1953) on siis edelleen tärkeä, vaikka naapuruus ei enää määrity yksinomaan maantieteellisin perustein niin kuin ennen.

\section{Johtopäätökset}

Viljelijät näkevät suomalaisen kasvinviljelyn tulevaisuudessa monia uhkia: tuotanto yksipuolistuu ja peltojen kunto heikkenee, maatalouspolitiikka suosii yksipuolista kasvinviljelyä ja viljelijät valitsevat helppoja viljelykasveja. Kyselyn toteuttamistapaan nähden hyvä vastausprosentti ja viljelijöiltä saatu myönteinen palaute kuitenkin osoittivat, että kiinnostusta erikoiskasviviljelyyn on. Erikoistuminen koetaan yhdeksi mahdollisuudeksi jatkaa tai monipuolistaa tilan toimintaa ja erityisesti ne viljelijät, joilla tuotantoa koskeva päätöksenteko on nyt ajankohtainen olivat erittäin kiinnostuneita erikoiskasviviljelystä.

Vaikka kasvinviljely on yhä voimakkaammin sidoksissa tukijärjestelmiin, viljelijät uskovat erikoiskasviviljelyn lisääntymisen olevan riippuvainen ensisijaisesti markkinoiden kehityksestä. Sopimustuotannon lisääminen sekä jatkojalostuksen ja pitkäjänteisen tukipolitiikan kehittäminen ovatkin ensimmäisiä tehtäviä erikoiskasvituotannon lisäämisessä. Ympäristötuen kautta maksettava monimuotoisuustuki saattaisi toimia kannustimena, mutta se ei välttämättä yksinään riitä näiden kasvien laajamittaisemman viljelyn tueksi.

Vastaajat siis jakautuivat kiinnostuksensa perusteella viiteen ryhmään, joista erikoiskasveja viljelleet muodostavat noin yhden neljänneksen. Erittäin kiinnostuneita viljelijöitä on noin $15 \%$, joista merkittävä osa todennäköisesti voitaisiin kohtuullisin panostuksin (esim. tiedottamisessa) saada mukaan erikoiskasviviljelyn piiriin. Suurin ryhmä, erikoiskasveista mahdollisesti kiinnostuneet (IV) ryhtyvät todennäköisemmin viljelemään vasta, kun he voivat varmistua viljelyn taloudellisesta kannattavuudesta. Selvästi muista ryhmistä poikkesivat innovaation torjujat, jotka ovat hyvin epätodennäköisiä erikoiskasviviljelijöitä missään olosuhteissa mm. siitä syystä, että heidän mielestään maatalouden ensisijainen tehtävä on tuottaa elintarvikkeita. Lisäksi monet heistä ovat eläintuottajia ja haluavat pitää tilan kasviviljelyn suhteellisen yksinkertaisena.

Erikoiskasviviljelyn lisääntymistä voidaan tukea tiedottamisen, neuvonnan ja tutkimuksen avulla. Tiedon ja muun tuen tarve vaihtelee omaksumisprosessin eri vaiheissa: tietoa tarvitaan aloittamispäätöksen tekemisessä, mutta myös viljelyn eri vaiheissa. Henkilökohtaista opastusta ja tukea tarvitsevat erityisesti erikoiskasviviljelystä hyvin kiinnostuneet, jotka kiinnostuksestaan huolimatta ovat hieman arempia ottamaan riskejä. Viljelijäyhteisöllä ja päivittäisellä 
vuorovaikutuksella on tutkimuksen mukaan yhä tärkeä merkitys uusien innovaatioiden omaksumisessa. Ylipäänsä viljelijät haluaisivat tehdä toistensa kanssa yhteistyötä nykyistä enemmän. Koulutustilaisuuksissa tai internetissä voi syntyä uusia kontakteja ja verkostoja, mutta myös suoraa, kasvokkaista vuorovaikutusta tarvitaan. Internet on keskeinen tiedonsaantikanava tähän kyselyyn vastanneille, ja esimerkiksi erikoiskasviviljelyä käsitteleville internetsivuille saattaisi olla kysyntää. Perinteisen neuvonnan rinnalle tarvitaan uudentyyppisiä tilaisuuksia, joissa toteutuu yhtäältä viljelijöiden välinen kanssakäyminen, mutta myös tiedollinen ja neuvonnallinen tuki. Maisemallisesti näyttävien erikoiskasvien viljely julkisilla tiloilla ja maisemallisesti merkittävillä paikoilla yksi tapa lisätä innostusta kasvien viljelyyn, vaikka maisemalliset tekijät eivät tutkimuksessa nousseet kovin merkittäviksi päätöksentekoa ohjaaviksi tekijöiksi. Erikoiskasveja voisi markkinoida myös maatalouden ympäristötuen mukaisten kesantojen ja monivuotisten viherkesantojen kasvivaihtoehtoina perinteisten kasvien sijaan. Lisäksi erikoiskasvien sopivuutta viljelykiertoihin ja viljelykasvilajiston monipuolistamisessa voisi tuoda voimakkaammin esiin.

Tässä tutkimuksessa on tarkasteltu sitä, miten viljelijät suhtautuvat erikoiskasviviljelyyn. Tutkimuksen perusteella voidaan todeta, että moni viljelijä voisi ryhtyä tietyin edellytyksin erikoiskasvin viljelijäksi. Jotta näin tapahtuisi, tarvitaan koko sektorin, jatkojalostuksen, markkinoinnin ja ohjauskeinojen kehittämistä. Erikoiskasvituotteille pitää saada kysyntää, lisätä sekä viljelijöiden että kuluttajien tietoisuutta erikoiskasviviljelyn hyödyistä ja mahdollisuuksista, ja sitä kautta luoda tuotantotavalle yhteiskunnallista kiinnostavuutta ja hyväksyttävyyttä. Lisäksi on huomattava, että ennen kuin viljelijöitä ryhdytään laajamittaisesti kannustamaan erikoiskasviviljelyyn, myös ketjun muun osien toimivuudesta ja kehittämisestä pitää olla varmuus.

\section{Kirjallisuus}

Council of the European Union. 2003. CAP Reform - Presidency compromise (in agreement with the Commission). Available in the Internet: http://register.consilium.eu.int/pdf/en/03/st10/st10961en03.pdf. Viitattu: 2004-05-13.

Guerin, T. F. 2001. "Why sustainable innovations are not always adopted." Resources, Conservation and Recycling vol. 34 (2001): 1-18.

Hägerstrand, T. 1953. Innovationsförloppet ur korologisk synpunkt. Meddelanden från Lunds Universitets geografiska institution avhandlingar XXV. Lund: Lunds Universitet.

Keskitalo, M. 2000. Erikoiskasvien viljelyn kehittämishanke 1997 - 2000 : loppuraportti.

Lehtinen, J. \& Salo, J. 2000. Onko luomuviljelijöissä jotakin erikoista? Maaseudun Uusi Aika: 1/2000: 8-22.

Luostarinen, Matti (2004): Innovaatiostrategia ja -kapasiteetti. Ekologinen klusteri ja innovaatiopolitiikka. Maa- ja elintarviketalouden tutkimuskeskus. Maa- ja elintarviketalous 45.

Maatilarekisteri 2002. Maa- ja metsätalousministeriön tietopalvelukeskus, 2003, Helsinki.

Niemi, J \& Pietola, K. 2005. "Maatalouden rakennekehitys väistämätöntä.” Suomen maatalous ja maaseutuelinkeinot 2005 : kymmenen vuotta Euroopan unionissa. MTT Taloustutkimus. Julkaisuja 105: 25.

Rice, W. R. 1989. “Analyzing tables of statistical tests.” Evolution, vol. 43, No. 1: 223-225.

Rogers, E. M. 2003. Diffusion of Innovations. Fourth Edition. The Free Press, New York.

Roslakka, J. 2005. Luomutuotanto ja innovaation omaksuminen. Luonnonmukaisen tuotannon omaksumiseen Pohjois-Karjalassa vaikuttaneet sosiaaliset spatiaaliset ja taloudelliset tekijät. Joensuun yliopiton yhteiskuntatieteellisiä julkaisuja N:o 76. Joensuun yliopisto.

Zar, J. H. 1999. Biostatistical Analysis. Fourth edition. Prentice Hall, Upper Saddle River, New Jersey. 